\title{
PERAN SAYYIDAH 'AISYAH DALAM PEMBENTUKAN HUKUM ISLAM BERWAWASAN GENDER
}

\author{
Ahmad Izzuddin \\ Fakultas Syariah UIN Maliki Malang \\ Telepon: 08155130764
}

\section{Abstract}

Islamic law and women are one of mostly debated discourses by contemporary Islamic thinkers particularly those who are gender issues proponents. That discourse grows due to the accuse towards Islam that this religion is the source of gender inequality for women through out muslim world especially in education, fairness and domestic freedom as well as social welfare in the family. The assumption is that Islamic law is male-based law. Therefore, it is a need to explore the note on Islamic law development which is perceived from the role of women in the early age of law construction not from the aspect of the thought of classical ulama in the middle age. This paper tries to explore and to discuss mainly the role of Siti Aisyah as the teacher and the transmitter of hadith as the foundation of Islamic law construction to underline women's position and contribution as the law maker that it will prove that Islamic law is not merely men-based law as the assumption grows.

Hukum Islam dan perempuan adalah kajian yang banyak diperdebatkan oleh para pemikir muslim kontemporer terutama bagi kelompok yang mendukung isu-isu gender. Kajian tersebut berkembang disebabkan oleh tuduhan terhadap Islam sebagai agama atau sumber yang menyebabkan ketidakadilan gender diseluruh belahan dunia Islam terutama dalam bidang pendidikan, keadilan, kebebasan dalam rumah tangga dan kesejahteraan sosial dalam rumah tangga. Asumsi yang dibangun adalah bahwa hukum Islam bersifat hukum laki-laki. Oleh karena itulah, adalah suatu keharusan untuk mengeksplorasi catatan dari perkembangan hukum Islam dilihat dari aspek peran perempuan pada awal-awal pembentukan hukum, bukan dari aspek pemikiran ulama klasik pada abad pertengahan. Makalah ini berusaha untuk mengeksplorasi dan mendiskusikan peran utama dari Siti Aisyah sebagai guru dan transmitter dari hadist sebagai 
dasar dari pembentukan hukum Islam sebagai landasan dari pembentukan hukum Islam untuk menggarisbawahi posisi dan kontribusi perempuan sebagai pembuat hukum yang akan menunjukkan bahwa hukum Islam tidak semata-mata hukum laki-laki sebagaimana asumsi yang berkembang.

Keywords: hukum islam, wawasan gender

\section{Pendahuluan}

Dalam banyak kesempatan banyak sekali pertanyaan mengenai sejauh mana sosok perempuan memberikan sumbangsih dalam perkembangan hukum Islam. Bidang hukum Islam dianggap oleh banyak pihak sebagai wilayah kajian maskulin. Pandangan tersebut dianggap benar oleh sebagian pihak, mengingat pada kenyataannya sangat sedikit sekali sosok perempuan yang hadir dan dapat memberikan warna dalam kajian hukum Islam. Sedikit sekali seorang faqih (ahli fiqh) perempuan yang dianggap memenuhi kualifikasi sebagai seorang mujtahid.

Pandangan tersebut tidaklah sepenuhnya benar, apalagi jika dikaitkan dengan alasan gender bahwa seorang perempuan tidaklah memenuhi persyaratan menjadi seorang mujtahid atau ahli fiqh terkemuka karena rendahnya kemampuan akal mereka di dalam menganalisis dan merumuskan hukum sebagaimana pemahaman mereka terhadap hadist bahwa kebanyakan penghuni neraka adalah perempuan (Bukhari, 1994: 12). Terlebih lagi hukum dalam pandangan mereka memang ditetapkan untuk mengatur dan bahkan membatasi ruang gerak perempuan dalam kehidupan.

Diakui, memang sangat sedikit sosok perempuan yang dikenal masyarakat sebagai sosok yang memiliki pengaruh dalam perkembangan pemikiran hukum Islam, namun hal itu. bukanlah hal yang dapat dijadikan justifikasi terhadap stigma negatif tersebut.

Pada dewasa inipun pemikir hukum Islam dari perempuan juga sangatlah terbatas. Hal tersebut bisa jadi merupakan ironi akademis melihat bahwa sejauh ini sudah sangat banyak sekali lembaga-lembaga pendidikan Islam baik yang formal seperti sekolah-sekolah dan perguruan tinggi memberikan ruang yang sangat luas bagi para perempuan untuk masuk ke dalam dunia pendidikan hukum Islam. Begitu juga banyak sekali pesantren-pesantren yang dikhususkan untuk kaum perempuan. Namun 
hal tersebut kurang memberikan sumbangsih terhadap kemunculan tokoh intelektual perempuan dalam wacana pengembangan hukum Islam.

Secara historis, kemunculan para perempuan dalam pengembangan Islam secara umum dan hukum Islam secara khusus, sudah ada semenjak zaman Rasulullah saw dan para sahabat. Di antara tokoh yang terkemuka dan memiliki peran yang sangat penting adalah Sayyidah 'Aisyah ra. Hal ini sejatinya harus menjadi pendorong bagi para akademisi muslimah dan santri perempuan untuk berkiprah dan memberikan warna bagi perkembangan wacana hukum Islam dewasa ini.

Wacana gender yang menjadi diskursus pada akhir-akhir ini mengerucut pada tiga tema besar yaitu pendidikan sebagai modal pengembangan sumber daya perempuan yang masih tertinggal, kemerdekaan dalam pernikahan dan keadilan dan jaminan kesejahteraan dalam wilayah domestik rumah tangga. Pengaruh 'Aisyah ra dalam tiga tema besar tersebut akan menjadi kajian pada kesempatan kali ini.

\section{Perempuan dan Stigma Pelanggaran Hukum Agama}

Beberapa mufassir memahami penyebab turunnya Adam dari surga adalah karena godaan Hawa sehingga dengan demikian beban dosa tersebut merupakan tanggung jawab pihak semua perempuan keturunannya. Hukuman tersebut dibebankan dengan adanya haidh yang dialami oleh semua perempuan. Begitu juga pandangan beberapa muhaddist yang banyak meriwayatkan hadist-hadist yang berpotensi menyebarkan kebencian kepada perempuan (misoginis) (Sahrur, 2004: 498-499). Perempuan juga dianggap inferior dari segi intelektual dan moral. Seringkali ditemukan dalam literatur pada agama-agama yang menggambarkan perempuan sebagai binatang yang tidak memiliki jiwa. Dalam tradisi kitab Bible, diterangkan bahwa perempuan diciptakan dari tulang rusuk Adam untuk menjadi teman baginya. Oleh karena perempuan adalah makhluk kedua setelah laki-laki (Engineer, 2003: 65).

Di dalam riwayat hadist terdapat juga hadist-hadist yang digunakan untuk menafsirkan surat al-Nisa: 1: wahai sekalian manusia bertaqwalah kepada Tuhanmu yangtelah menciptakan kamu dari seorang diri (nafs wahidah) dan dari padanya Allah menciptakan istrinya....". Ibn Katsir memaknai nafs wahidah sebagai Adam a.s. (Katsir, 1997 : 493). Penafsiran tersebut berdasarkan pada hadist riwayat Muslim yang menerangkan "bahwa 
wanita diciptakan dari tulang rusuk laki-laki” (Muslim, tt: 178). Namun semua konteks hadist yang menerangkan hal tersebut tidaklah berpretensi untuk meletakkan perempuan pada posisi yang rendah dan inferior akan tetapi merupakan keharusan bagi laki-laki untuk memperlakukan perempuan dengan cara yang sebaik mungkin. Hal tersebut dapat dilihat secara jelas bahwa para penulis-penulis hadist seperti Imam al-Bukhari, Muslim, al-Tirmidzi dan lain-lain selalu meletakkan hadist-hadist tersebut di dalam bab keharusan berbuat lembut kepada perempuan dan bab berwasiat kebaikan kepada para perempuan (Nurjannah, 2003: 269)

Stigma bahwa perempuan adalah sosok yang mudah digoda syetan juga tidak memiliki dasar kuat dalam al-Qur'an maupun Hadist Rasulullah saw, akan tetapi sedikit banyak dipengaruhi oleh riwayat-riwayat isra'iliyyat yang menerangkan secara detail bagaimana Hawa membujuk Adam untuk mengikuti ajakan Iblis memakan buah "khuldi". Di dalam al-Qur'an secara jelas disebutkan bahwa yang terbujuk oleh Iblis adalah kedua Adam dan Hawa tidak salah satu saja. Demikian juga teks-teks alQur'an yang menceritakan proses turunnya Adam dan Hawa dari surga selalu menggunakan kata ganti tashniyah (dua orang).

Al-Qur'an Q.S. al-Baqarah: 35: “:Dan Kami berfirman: Hai Adam diamilah oleh kamu dan istrimu surga ini, dan makanlah makananmakanannya yang banyak lagi baik di mana saja kamu sukai, dan janganlah kamu berdua mendekati pohon ini, yang menyebabkan kalian termasuk orang-orang yang dzalim”. Awal kisah pelanggaran keduanya ketika terbujuk Iblis juga diterangkan secara gamblang di dalam Q.S. al'A'raf: 20: "Maka syetan membisikkan pikiran jahat kepada keduanya untuk menampakkan kepada keduanya yang tertutup dari mereka (aurat) dan syetan berkata: Tuhan kalian tidak melarangmu dari mendekati pohon ini, melainkan agar kamu berdua tidak menjadi malaikat atau tidak menjadi orang yang kekal dalam surga". Proses bagaimana keduanya terbujuk oleh Iblis dilanjutkan pada Q.S. al-A'raf: 22: “Maka syetan membujuk keduanya (untuk memakan buah itu) dengan tipu daya. Tatkala keduanya telah merasai buah kayu itu, tampaklah aurat keduanya. Lalu Tuhan menyeru mereka: Bukankah Aku telah melarang kalian berdua dari pohon itu dan Aku katakan kepada kalian: sesungguhnya syetan itu adalah musuh yang nyata bagi kalian berdua”. 
Pernyataan-pernyataan dalam al-Qur' an tersebut sangatlah berbeda dengan pernyataan-pernyataan yang termuat dalam Al kitab yang lebih banyak membebankan kesalahan kepada Hawa. Dengan demikian anggapan stigma terhadap perempuan sebagai makhluk penggoda sesungguhnya tidak memiliki dasar yang jelas di dalam Islam. Bahwa perempuan adalah makhluk yang dapat menggoda laki-laki tentu benar sebagaimana laki-laki juga menjadi penggoda bagi perempuan. Dan inilah hakekat kehidupan dunia yang merupakan cobaan bagi semua manusia yang menghuninya sebagaimana tercantum dalam Q.S al-Mulk: 1.

Kesadarana inilah yang meletakkan para wanita di awal-awal Islam memiliki peran-peran strategis di dalam pengembangan agama dan hukum Islam. Kaum perempuan tidaklah selalu menjadi obyek pembahasan hukum akan tetapi ia juga merupakan subyek hukum yang dapat menentang hukum yang dirasa tidak benar. Hal tersebut tercermin dalam kasus di mana suatu saat Khalifah Umar menetapkan batas maksimum mahar yang tidak boleh melebihi empat ratus dirham. Dalam ketetapannya ia berkata: janganlah kalian bermahal-mahal dalam pemberian mahar kepada para istri kalian karena apabila mahar tersebut merupakan cerminan kemulian dunia dan ketaqwaan di akherat maka tentu Rasulullah saw lebih utama dalam hal tersebut padahal Ia tidak pernah memberi untuk istri-istri dan putri-putrinya mahar yang melebihi dua belas uqiyah perak (400 dirham). Maka barang siapa yang memberi mahar melebihi empat ratus dirham akan diserahkan ke baitul mal. Ketika Umar Ibn Khattab selesai dan turun dari mimbar ada seorang wanita Quraisy berkata kepadanya: "hal tersebut bukanlah menjadi urusan kamu wahai Umar". Umar ra bertanya mengapa? Wanita tersebut menjawab karena Allah swt berfirman: “..... sedang kalian telah memberikan kepada seseorang di antara mereka harta yang banyak". Setelah Umar meralat ucapannya dan mempersilahkan kaum laki-laki memberi mahar lebih dari 400 dirham tanpa ada batasan maksimal (al-Maraghi, 2001: 124).

Dalam konteks itulah kaum perempuan pada masa Rasulullah, khususnya para istri-istri Rasul sebagai ibu dari kaum muslimin memiliki tanggung tanggung jawab yang besar untuk mengajarkan agama dan hukum Islam kepada kaum muslimin. Hal tersebut diterangkan dalam al-Qur'an: al-Ahzab: 34: "Terangkanlah apa yang dibacakan di rumahmu dari ayat- 
ayat Allah dan hikmah (sunnah Nabi). Sesungguhnya Allah adalah Maha Lembut dan Maha Mengetahui."

Peran pengajaran tersebut dijalankan dengan sangat baik oleh salah seorang istri Rasululllah saw yang bernama "Aisyah ra yang memiliki peran sangat luar biasa dalam periwayatan hadist-hadist Nabi dan merupakan cermin dari tokoh perempuan muslim terkemuka yang sangat mempengaruhi fiqh Islam, kehidupan berfikir, beragama dan berpolitik bagi kaum muslimin (al-Baghdady, 2001: 36).

\section{Biografi ‘Aisyah Ra}

'Aisyah ra. adalah puteri dari Shahabat Abu Bakr al-Shidiq r.a. Beliau diberi kuniyah sebagai Ummu 'Abdillah. Ibunda 'Aisyah adalah Ummu Ruman binti 'Amir ibn 'Uwaimir ibn Syams ibn'Attab ibn Udzainah ibn Subai' ibn Duhman ibn al-Harist ibn Ghanam ibn Malik ibn Kinanah (al-Mazzy, 1994: 372). Sayyidah 'Aisyah merupakan istri ketiga Rasulullah yang dinikahi setelah wafatnya Sayyidah Khadijah. Pernikahan tersebut dilangsungkan di Makkah dua tahun sebelum hijrah di usianya yang ke enam tahun. Akan tetapi 'Aisyah ra hidup serumah dengan Rasulullah ketika ia berusia 9 tahun pada bulan Syawwal delapan belas bulan setelah hijrahnya Rasulullah saw di Madinah. Hadist mengenai hal ini diriwayatkan dalam kitab Bukhari dan Muslim sedangkan riwayat lain dari al-Tabari menyatakan bahwa 'Aisyah ra menikah dengan Rasulullah pada usia di atas 10 tahun dan berkumpul dengan Rasul pada usia 13 tahun sedangkan menurut perhitungan 'Abd Rahman ibn Abi Zannad, 'Aisyah ra dinikahi Rasulullah pada usia 17 atau 18 tahun dan hidup serumah dengan Rasulullah saw pada usia 20 tahun (Antonio, 2010: 55-56).

'Aisyah ra adalah satu-satunya perempuan yang dinikahi Rasulullah saw dalam kondisi perawan bukan janda dari laki-laki lain. Proses pernikah itu sendiri merupakan inisiatif dari sahabat perempuan bernama Khaulah binti Hakim yang merasakan kesedihan Rasulullah saw sepeninggal istri tercinta Sayyidah Khadijah. Inisiatif tersebut juga didukung oleh sahabatsahabat yang lain yang mempercayakan hal tersebut kepada Khaulah untuk menawarkannya kepada Rasulullah saw. Dalam riwayat lain diceritakan bahwa sebelum menikah dengan Rasulullah sesungguhnya 'Aisyah ra sudah bertunangan dengan Jubair ibn Muth'im ibn 'Adi, namun ibunda dari Jubair tidak mengizinkan putranya menikah dengan 'Aisyah ra kecuali 
Ia mau berpindah agama. Mendengar hal tersebut Abu Bakr ra menganggap bahwa pertunangan tersebut telah batal dan putus. Kesedihan Abu Bakr ra terobati ketika mendengar Rasulullah berkenan untuk menikah dengan 'Aisyah ra. Riwayat lain menerangkan bahwa Rasulullah saw mempersunting 'Aisyah ra berdasarkan perintah Allah swt melalui wahyu dalam mimpi. Nabi Muhammad saw memberitahukan kepada 'Aisyah ra bahwa Beliau melihat 'Aisyah ra dalam mimpinya selama tiga hari ketika itu ada malaikat yang berkata "ini adalah istrimu. Ketika Rasulullah saw ungkap tirai tersebut terlihatlah wajah 'Aisyah ra (Bukhari, 1995: 368).

Pernikahan Rasulullah dengan 'Aisyah ra tidaklah dikarunia putera. Kenyataan tersebut yang sering mengganggu perasaannya karena tidak dapat memberikan keturunan pada Rasulullah saw. Untuk mencurahkan perasaan keibuannya 'Aisyah ra mengadopsi seorang anak laki-laki bernama Abdullah ibn Zubair ra putra dari saudaranya yang bernama Asma binti Abu Bakr ra sehingga Ia diberi kuniyah Ummi Abdillah. 'Aisyah ra juga mengadopsi Qasim ibn Abdurrahman ra putra Abdurrahman Ibn Abu Bakr ra.

Selama dalam masa pernikahan dengan Rasulullah saw banyak sekali cobaan yang menimpa dalam kehidupan rumah tangga. Di antara cobaan yang terberat adalah tuduhan orang-orang munafiq kepadanya telah berselingkuh dengan Safwan ibn al-Mua'athtal. Peristiwa tersebut dinamakan dengan hadist al-ifki. Tuduhan tersebut sangatlah mengguncang Rasulullah saw dan 'Aisyah ra sendiri. Tuduhan tersebut bahkan menyebabkan 'Aisyah ra sakit selama berbulan-bulan. Peristiwa tersebut diterangkan dalam kitab Bukhari dan Muslim dan dikenal dengan hadist al-ifki (Muslim, tt: 112). Guncangan fitnah tersebut berakhir setelah secara jelas Allah swt membantah tuduhan tersebut dalam Q.S. al-Nur:"sesungguhnya orang-orang yang membawa berita bohong itu adalah dari golongan kamu juga. Janganlah kamu kira berita bohong itu buruk bagi kamu bahkan ia adalah baik bagi kamu. Tiap-tiap seorang dari mereka mendapat balasan dari dosa yang dikerjakannya. Dan siapa yang mengambil bahagian yang terbesar dalam penyiaran berita bohong itu baginya azab yang besar".

Keutamaan 'Aisyah sering sekali berpuasa dan membagikan harta kepada orang yang membutuhkan (al-Kandahlawi, 2006: 242). Beliau 
wafat di Madinah pada masa khilafah Mu'awiyah ibn Abi Sufyan pada tanggal 17 Ramadhan tahun 8 Hijriyah pada usia 66 tahun. 'Aisyah ra dimakamkan di pemakaman Baqi' di kota Madinah sesuai dengan wasiatnya. Bertindak sebagai imam shalat jenazahnya adalah sahabat Abu Hurairah ra.

\section{Peran 'Aisyah Ra. dalam Periwayatan Hadist}

Hadist sebagai salah satu sumber hukum yang utama setelah alQur'an memilki peran yang sangat sebagai muakkid (penguat), muqayyid, mubayyin, mukhassih dan bahkan sebagai nasikh maupun pembuat hukum yang tidak diterangkan di dalam al-Qur'an (Khallaf, 1978: 39-40). Ulama bersepakat bahwa orang yang mengingkari kehujjahan hadist Nabi dapat dikategorikan sebagai orang kafir (Hito, 2005: 90).

Allah swt dalam Q.S. al-Hasyr: 7, secara jelas menyatakan bahwa: "Apa yang diberikan Rasul kepadamu maka terimalah dan apa yang dilarang olehnya maka tinggalkanlah”. Posisi tersebut menjadikan Rasulullah saw memilki otoritas dalam menetapkan suatu hukum. Dalam Q.S. al'A'raf: 158 Allah swt berfirman untuk memerintahkan kepada Nabi agar mengatakan: “ wahai manusia sesungguhnya aku adalah utusan Allah Yang mempunyai kerajaan langit dan bumi, tidak ada Tuhan selain Dia. Maka berimanlahkamu kepada Allah dan RasulNya, Nabi yang ummi yang beriman kepada Allah dan kepada kalimat-kalimatnya dan ikutilah dia agar kalian mendapatkan petunjuk". Ayat ini berisi perintah untuk beriman kepada Allah dan RasulNya, dengan konsekwensi mematuhi perintah-perintah, aturan-aturan dan sunnah-sunnahnya. Dan manusia tidak mungkin memperoleh petunjuk dari ajaran-ajaran Rasul tanpa mengikuti ajaran-ajaran yang tercantum dalam sunnahnya. Hanya percaya dengan hati tanpa dibarengi dengan pengamalan yang baik terhadap aturan sunnah menjadikan keimanan seseorang tidaklah sempurna bahkan ditolak (Azami, 2000: 30-31).

Urgensi tersebut menjadikan hadist sebagai salah satu kajian yang begitu penting untuk menggali hukum Islam. Para sahabat begitu bersusah payah untuk menghimpun hadist-hadist Rasulullah saw. Mereka menempuh perjalanan yang sangat jauh untuk mencari jalur transformasi untuk meriwayatkan hadist agar terjamin otentitas sanadnya. Sebagai contoh adalah sahabat Jabir ibn Abdillah yang mencari kebenaran suatu 
hadist yang belum pernah ia dengar sehingga ia melakukan perjalanan ke Syam untuk mengetahui sumber hadist itu dari Sahabat Abdullah ibn Unais al-Anshari. Hal itu Ia lakukan karena takut apabila ia meninggal atau sahabat yang meriwayatkan hadist tersebut meninggal sebelum ia mendengar hadist tersebut secara langsung (al-Siba'i, 1979: 114-115).

Oleh karena itu, ada beberapa sahabat Rasulullah yang dikenal sebagai penjaga dan penyampai hadist-hadist Rasulullah saw. untuk mentransformasikannya kepada kaum muslimin. Urutan enam besar di antara mereka adalah:

a. Abu Hurairah ra. yang meriwayatkan 5373 hadist

b. Ibnu Umar yang meriwayatkan 2630 hadist

c. Anas ibn Malik yang meriwayatkan 2286 hadist

d. 'Aisyah ra yang meriwayatkan 2210 hadist

e. Ibn Abbas yang meriwayatkan 1660 hadist

f. Jabir Ibn Abdillah yang meriwayatkan 1540 hadist (Thahhan, tt, 165)

Pada posisi ini 'Aisyah ra menempati rangking yang keempat. Akan tetapi apabila dilihat dari posisinya terhadap hadist-hadist yang terkait dengan perempuan Beliau adalah sebagai penyampai paling utama terhadap hadist-hadist tersebut. Peran 'Aisyah ra sangatlah penting di mana ia dikenal sebagai orang yang paling alim dan banyak dijadikan rujukan tokoh-tokoh sahabat Rasulullah saw dalam masalah-masalah hukum. Beliau banyak dipuji sebagai sosok yang paling mengerti agama dan paling baik pemikirannya. Al-Zuhri berkata bahwa apabila semua ilmu istri-istri Rasulullah dikumpulkan menjadi satu maka ilmu 'Aisyah ra melebihi itu semua. Sahabat Musa al-Asy'ari juga berkata apabila para sahabat mengalami kesulitan dalam suatu hadist maka rujukan para sahabat adalah 'Aisyah ra. oleh karena itu lebih dari 100 sahabat yang meriwayatkan hadist dari 'Aisyah ra (al-Mazzy, 1994: 376-377).

Sayyidah “Aisyah ra sebagaimana istri-istri Rasulullah saw yag lain memiliki peran yang penting dalam periwayatan dan bahkan pemberian fatwa. Hal tersebut dapat dilihat pasca wafatnya Baginda Rasulullah saw di mana mereka memiliki kelebihan dalam menjaga, mengajarkan dan menyebarkan sunnah Nabi. Lebih khusus sunnah Nabi yang terkait dengan 
urusan rumah tangga. Tempat tinggal para istri Nabi seakan-akan menjadi madrasah-madrasah bagi umat Nabi untuk mengambil lautan ilmu dan sunnah Nabi. Dan istri Nabi yang memiliki peran yang paling besar dalam hal tersebut adalah Sayyidah 'Aisyah ra. Di mana Ia memerankan fungsi tersebut secara sempurna. Banyak hadist-hadist di mana 'Aisyah ra merupakan perawi tunggalnya tidak ada sahabat lain yang meriwayatkan hadist tersebut selainnya. Seandainya tidak ada 'Aisyah ra maka akan hilanglah bagian yang besar dari sunnah-sunnah Nabi saw khususnya hadist-hadist yang bersifat fi'liyyah (action). 'Aisyah ra telah meriwayatkan lebih dari dua ribu hadist di mana seratus tujuh pulah empat hadist disepakati keshahihannya oleh Bukhari dan Muslim. Hanya Lima puluh empat hadist yang berbeda dicantumkan oleh Bukhari dalam kitab shahihnya dan enam puluh sembilan hadist yang berbeda dicantumkan oleh Muslim dalam kitab shahihnya (Shalih, 2008: 248).

\section{Peran Politik Hukum 'Aisyah Ra}

Sebagaimana telah diterangkan bahwa di dalam Islam semua manusia dengan tanpa melihat kelaminnya diberi tanggungjawab oleh Allah swt untuk melakukan amar ma'ruf dan nahi munkar. Allah berfirman dalam Q.S. al Taubah: 71 "Dan orang-orang yang beriman, lelaki dan perempuan, sebagian mereka adalah penolong bagi sebagian yang lain. Mereka memerintahkan mengerjakan kebaikan dan mencegah kemunkaran, mendirikan shalat, menunaikan zakat, dan mereka ta'at kepada Allah dan Rasulnya. Mereka itu akan diberi rahmat oleh Allah; sesungguhnya Allah Maha Perkasa lagi Maha Bijaksana. Allah swt juga berfirman Q.S. alAhzab:35 "Seesungguhnya laki-laki dan perempuan yang muslim, laki-laki dan perempuan yang mu'min, laki-laki dan perempuan yang tetap dalam keta'atannya, laki-laki dan perempuan yang benar (jujur), laki-laki dan perempuan yang sabar, laki-laki dan perempuan yang khusyu', laki-laki dan perempuan yang bersedekah, laki-laki dan perempuan yang berpuasa, laki-laki dan perempuan yang memelihara kehormatannya, laki-laki dan perempuan yang menyebut nama Allah, Allah telah menyediakan untuk mereka ampunan dan pahala yang besar".

Sayyidah 'Aisyah ra tidak hanya memerankan fungsinya sebagai perawi hadits tetapi lebih dari itu ia juga merupakan tokoh intelektual pada masanya yang sangat memahami al-Qur'an, sunnah Nabi dan bahkan ijtihad 
hukum. Banyak sahabat yang bertanya kepadanya mengenai permasalahan mereka sehingga posisinya sama dengan posisi seorang guru di hadapan murid-muridnya. Sahabat Umar ibn al-Khattab juga sering kali bertanya kepadanya mengenai hukum yang terkait dengan perempuan ataupun keadaan Rasulullah saw. Qasim ibn Muhammad berkata bahwa 'Aisyah ra sangat seringkali disibukkan dengan fatwa-fatwa pada masa khilafah Abu Bakr, Umar dan Ustman sampai wafatnya (Shalih, 2008: 247-249).

Peran aktif "Aisyah ra dalam menyebarkan dan mengkoreksi praktek keagamaan dan hukum Islam sangatlah luar biasa. Setiap kali ada hal yang dalam pandangan beliau salah maka seketika itu juga ia langsung akan mengkoreksinya. Sebagaimana pada suatu saat sampai di telinga 'Aisyah ra bahwa 'Abdullah ibn Umar memerintahkan para wanita untuk mengurai gelungan rambut mereka ketika akan mandi janabah. 'Aisyah ra langsung berkata "sungguh menakjubkan Ibn Umar memerintahkan para wanita untuk mengurai gelungan rambut mereka ketika mandi apakah ia tidak memerintahkan mereka untuk memotong rambut mereka saja? Sungguh saya pernah mandi bersama Rasulullah saw pada satu wadah dan tidaklah aku kecuali hanya membilas kepalaku sebanyak tiga kali siraman saja tanpa mengurai rambutku" (Shalih, 2008: 248).

Kebersamaan 'Aisyah ra dengan Rasululllah selama kurang lebih 8 tahun 5 bulan menjadikan 'Aisyah ra sebagai sosok yang dapat dikategorikan sebagai pemuka fiqh terbesar dari golongan shahabat Rasulullah saw selain 'Umar ibn Khattab ra dan Ali Ra .

\section{Pengaruh Hadist-Hadist Riwayat 'Aisyah Ra dalam Penetapan Hukum Islam}

Sebagaiman telah disebutkan bahwa peran periwayatan hadisthadist Rasulullah saw oleh 'Aisyah ra sangatlah besar sekali karena banyak hadist-hadist di mana 'Aisyah ra merupakan perawi tunggal dari hadist tersebut. Hadist-hadist 'Aisyah ra tidak hanya terkait dengan aspek-aspek kerumahtanggaannya dengan Rasulullah akan tetapi juga termasuk hal-hal yang bersifat ibadah dan bahkan jarimah.

Untuk itu ada beberapa hadist yang sangat penting di mana 'Aisyah ra merupakan sumber pertama periwayatan hadist tersebut. Hadist-hadist yang akan diuraikan merupakan hadist-hadist yang bernuansa pembelaan terhadap kaum perempuan. 


\section{A. Kebebasan perempuan untuk belajar}

Aspek pendidikan merupakan salah satu aspek yang sedikit tersentuh di dalam pemikiran Islam. Dalam berbagai data menunjukkan betapa timpangnya antara ilmuwan laki-laki dan ilmuwan perempuan dalam lintasan sejarah dunia Islam. Dunia pendidikan seolah-olah adalah dunia kaum laki-laki sedangkan kaum perempuan dituntut berilmu hanya sekedar untuk dapat membaca dan menulis saja.

Apabila ditelusuri sesungguh kondisi tersebut tidaklah monopoli dari situasi sosial masyarakat muslim saja. Akan tetapi hampir seluruh peradaban termasuk Eropa pernah mengalami masa-masa di mana kaum perempuan diletakkan pada posisi sub-ordinat dari kaum laki-laki dalam hal pendidikan.

'Aisyah ra dapat dikategorikan sebagai pendidik wanita pertama dalam dunia Islam. Di mana ia tidak hanya menjadi guru dari kaum perempuan akan tetapi juga menjadi guru bagi kaum laki-laki. Hal tersebut dapat dilihat dalam hadist di mana ada tiga kelompok laki-laki yang datang kepada istri-istri Nabi untuk bertanya mengenai ibadah Rasulullah saw (Bukhari: 1994: 253)

$$
\begin{aligned}
& \text { جاء ثلاثة رهط إلى بيوت أزواج النبي صلى الله عليه وسلم، يسألون عن } \\
& \text { عبادة النبي صلى الله عليه وسلم، فلما أخبروا كأهم تقالوها، فقالوا: وأين نحن } \\
& \text { من النبي صلى الله عليه وسلم؟ قد غفر له ما تقدم من ذنبه وما تأخر، قال } \\
& \text { أحدهـم: أما أنا فإني أصلي الليل أبدا، وقال آخر: أنا أصوم الدهر ولا أفطر، } \\
& \text { وقال آخر: أنا أعتزل النساء فلا أتزوج أبدا، فجاء رسول الله صلى الله عليه } \\
& \text { وسلم إليهم، فقال: اأنتم الذين قلتم كذا وكذا، أما والله إي لأخشاكم لله } \\
& \text { وأتقاكم له، لكني أصوم وأفطر، وأصلي وأرقد، وأتزوج النساء، فمن رغب عن } \\
& \text { سنتي فليس مني }
\end{aligned}
$$


Keterlibatan para kaum perempuan di dalam pendidikan diapresiasi oleh 'Aisyah ra di dalam hadistnya yang menyatakan:

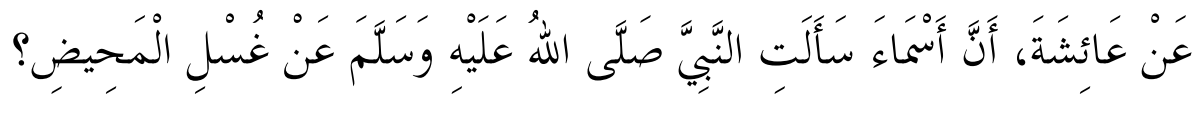

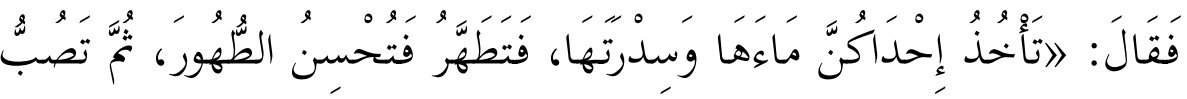

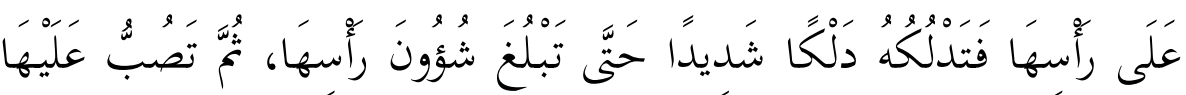

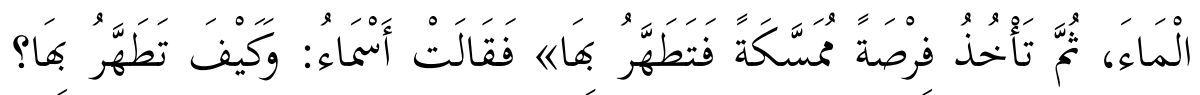

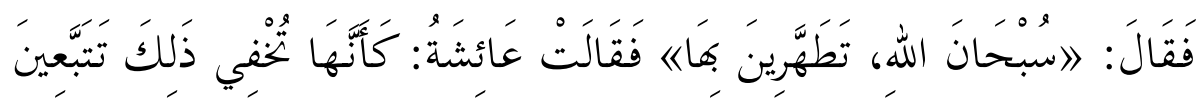

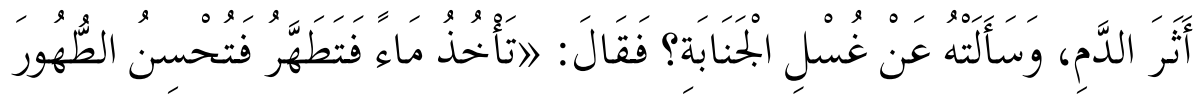

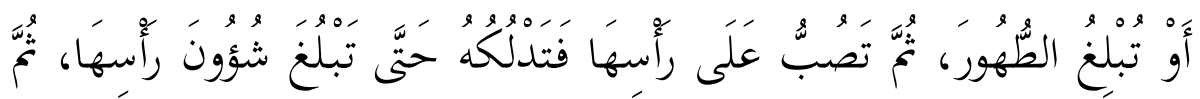

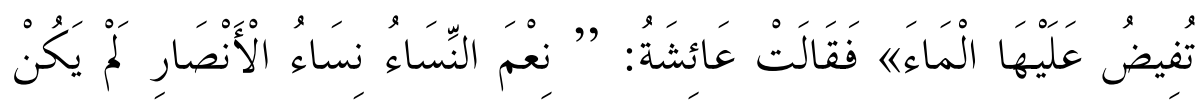

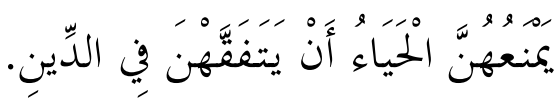

Artinya: “.....sebaik-baiknya kaum perempuan adalah wanitawanita Anshar yang tidak dihalangi rasa malu untuk mendalami ilmu agama (Daud, 2003: 87). Hadist ini didukung oleh hadist-hadist di Bukhari dalam Bab larangan malu dalam belajar, Muslim di Bab Thaharah, dan alTrimidzi dalam Bab cara orang wanita haidh mandi.

Hal ini merupakan dorongan motivasi kepada kaum perempuan untuk ikut aktif dalam pendidikan karena sabab wurud dari hadits ini sedikit banyak mengarah kepada hal tersebut.

Rasulullah saw sendiri menyediakan waktu khusus bagi para shahabat perempuan untuk belajar. Hal tersebut tercantum dalam hadist riwayat Abu Sa'id al-Khudri di mana Rasulullah saw menyediakan waktu khusus untuk kaum perempuan menimba ilmu kepada Nabi saw (Muslim, $\mathrm{tt}: 39)$. 


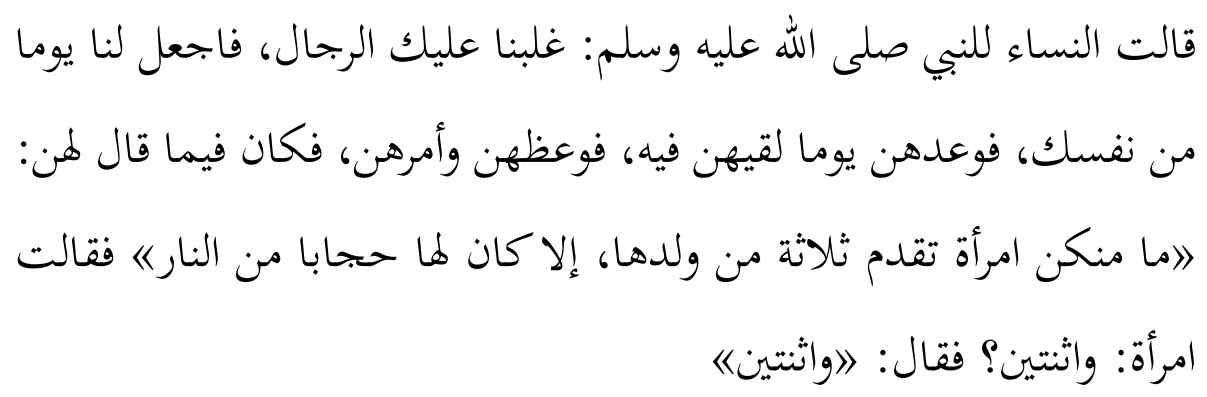

Artinya: Para sahabat perempuan berkata kepada Nabi saw: Kaum laki-laki telah mengalahkan Kami dalam hadist-hadist Mu maka jadikanlah untuk kami hari tertentu yang kosong agar kami dapat mengambil ilmu darimu. Nabi saw lalu menjajikan untuk mereka hari tertentu di mana Beliau dapat menemui mereka dan memberikan nasehat-nasehat dan perintah kepada mereka. Di antara perkataan Nabi kepada mereka adalah: "tidak ada seorangpun dari kalian wahai orang perempuan yang tiga putranya meninggal terlebih dahulu kecuali menjadi penutup neraka bagi kalian". Seorang wanita berkata: dua Wahai Rasulullah saw. Nabi menjawab: "iya dua juga".

Apresiasi Rasulullah saw terhadap para sahabat perempuan yang ingin belajar dengan menyediakan waktu khusus bagi mereka menyebabkan jumlah perawi hadist dari golongan sahabat perempuan sangatlah besar. Ahmad Ibn Hanbal dalam kitab musnadnya mencatat sebanyak 125 perawi hadist dari golongan sahabat perempuan. Akan tetapi disayangkan jumlah tersebut menurun dan terus menurun dari tingkat generasi ke generasi di bawahnya. Ibnu Hibban mencatat hanya 90 orang saja perawi perempuan dari golongan tabi'in (Munhanif. ed, 2002: 47-48).

Peran aktif kaum perempuan di awal-awal Islam baik sebagai pendidik -sebagaimana 'Aisyah ra- ataupun sebagai peserta didik merupakan bukti tidak adanya bias gender dalam tanggungjawab dalam mencari ilmu di dalam Islam sebagaimana hadist Rasulullah saw: siapapun yang menempuh suatu perjalanan untuk mencari ilmu maka Allah akan menjalankan dia pada jalan menuju surga (Daud, 2003: 180).

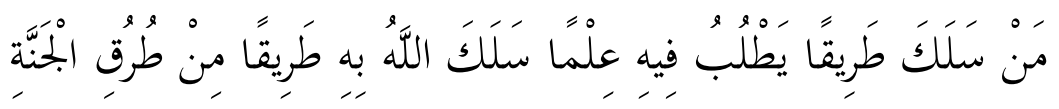




\section{B. Kebebasan wanita dalam menentukan suami}

Ada beberapa hadist di mana 'Aisyah ra merupakan sumber satusatunya dari riwayat tersebut yang menggambarkan bagaimana seorang perempuan memiliki hak prerogatif di dalam menentukan kelanjutan pernikahannya dengan seorang laki-laki.

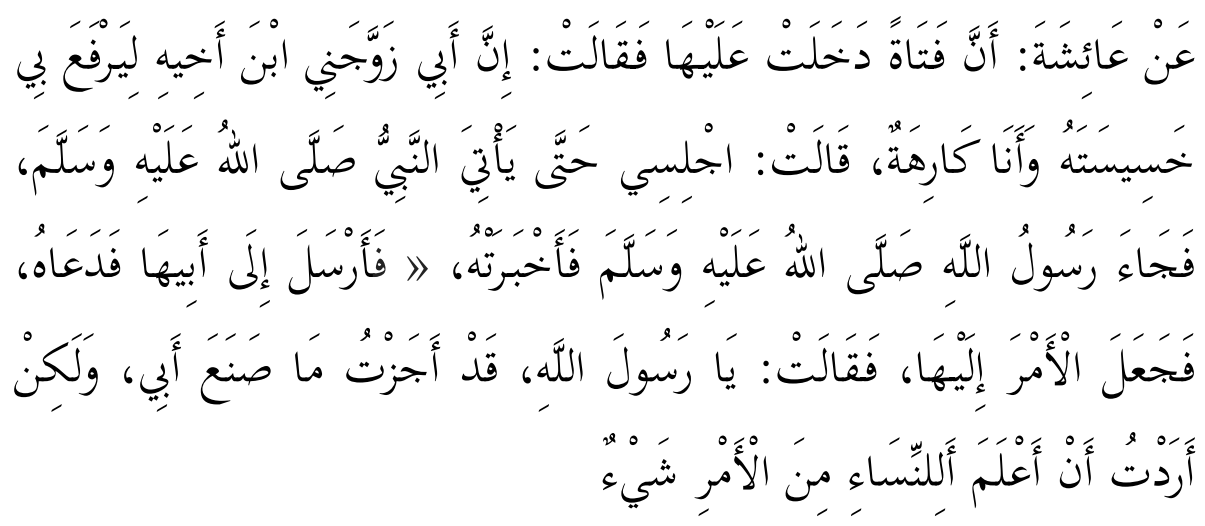

Artinya: dari 'Aisyah ra sesungguhnya ada seorang gadis yang menemuinya dan berkata:"sesungguhnya ayahku telah menikahkan aku dengan putra saudaranya (keponakan) agar sifat buruknya hilang dengan menikahiku padahal aku tidak menyukainya. 'Aisyah ra berkata: duduklah dan tunggulah Nabi saw tiba". Kemudian Nabi saw datang lalu perempuan tersebut menceritakan peristiwa tersebut kepadanya. Nabi kemudian memanggil ayah si perempuan dan menyerahkan persoalan perjodohan tersebut kepada anak perempuan tersebut. Perempuan tersebut kemudian berkata kepada Nabi saw: "wahai Rasulullah saw sesungguhnya aku menuruti apa yang ayahku lakukan akan tetapi aku hanya ingin memberitahukan kepada kaum perempuan bahwa sebenarnya seorang ayah tidak memiliki hak atas perjodohan ini sedikitpun (Nasa'i, 2005: 86).

Hak untuk memilih pemutusan hubungan perkawinan dalam riwayat 'Aisyah ra tidak hanya Rasulullah pernah terapkan pada kasus para sahabat, akan tetapi juga pernah Beliau terapkan pada perkawinan Beliau sendiri.

Hal tersebut digambarkan dalam hadist riwayat 'Aisyah ra:

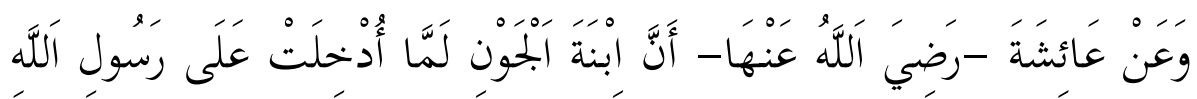




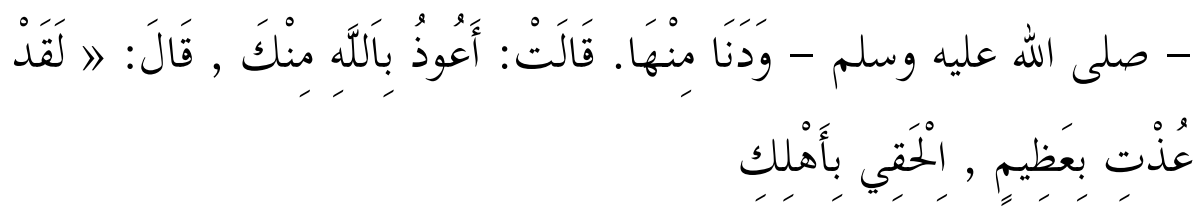

Artinya: diriwayatkan dari 'Aisyah ra bahwa 'Amrah bintial-Jauny ketika dinikahi Rasulullah saw dan di bawa masuk ke rumah Nabi dan Nabi mendekatinya Ia berkata: "aku berlindung kepada Allah swt dari engkau. Rasulullah saw berkata: "engkau sungguh telah berlindung dengan Dzat Allah yang Maha Agung. Kembalilah engkau kepada keluargamu (Majah, 2004: 643). Hadist riwayat ini juga diperkuat oleh riwayat Bukhari.

Hadist di atas memberikan gambaran kebesaran hati Rasulullah saw dalam menghormati hak-hak perempuan di dalam keputusannya untuk memutuskan pernikahan dengannya. Hal yang mungkin sulit ditemukan dalam ego seorang pemimpin laki-laki di dalam menerima penolakan dari seorang perempuan yang sesungguhnya adalah rakyat biasa bukan seorang putri raja ataupun putri dari orang yang terpandang.

Hadist-hadist di atas menjadi landasan penting bagi para Fuqaha, khususnya Imam Abu Hanifah dan para pengikutnya yang berpendapat bahwa seorang perempuan memiliki hak yang merdeka di dalam menentukan suaminya.

Menurut Imam Abu Hanifah seorang wanita yang merdeka, berakal dan sudah baligh baik ia masih bikr ataupun tsayyib dapat mengakadkan nikahnya sendiri dan dianggap sah meskipun tidak diakadkan oleh walinya. Bahkan seorang wanita mempunyai hak untuk menikahkan anak perempuannya yang masih kecil (Badr al-Din, 2000: 70).

Pendapat ini didasarkan kepada sumber-sumber hukum sebagaimana berikut:

\section{Al-Qur'an}

a. Q.S. Al-Baqarah: 230

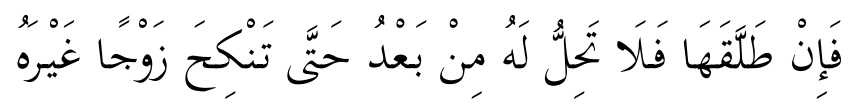

Artinya: Kemudian jika si suami mentalaqnya (setelah talaq yang kedua), maka perempuan itu tidak halal lagi baginya hingga dia kawin dengan laki-laki lain. 
b. Q.S. Al-Baqarah: 232

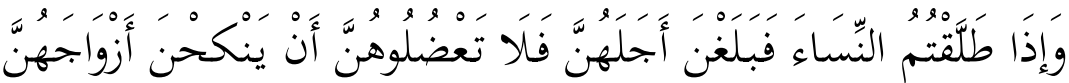

Artinya: Apabila kamu mentalaq istri-istrimu, lalu habis iddahnya, maka janganlah kamu (para wali) menghalangi mereka kawin lagi dengan bakal suaminya.

c. Q.S. Al-Baqarah: 234

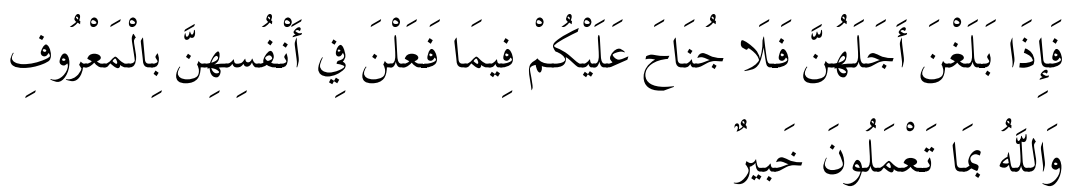

Artinya: Kemudian apabila telah habis iddahnya, maka tiada dosa bagimu (para wali) membiarkan mereka berbuat terhadap diri mereka sendiri.

Semua ayat di atas memberikan pengertian bahwa wanita memiliki hak penuh untuk menikahkan diri mereka sendiri karena yang menjadi mukhatab dari ayat di atas adalah si perempuan bukan wali atau orang lain.

\section{Sunnah Rasulullah saw}

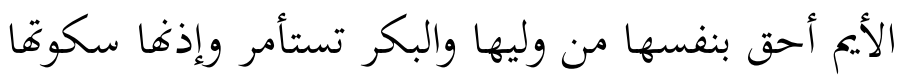

Artinya: Wanita yang tidak memiliki suami lebih berhak dari walinya seorang bikr dimintai persetujuan dan izinnya adalah diamnya (Muslim, tt: 140).

Hadist ini juga diriwayatkan Abu Daud dalam Kitab al-Nikah, alTirmidzi Kitab Nikah, Ibn Majah Kitab, al-Muwattha' Kitab Nikah dan Musnad Ahmad ibn Hanbal.

Lafadz al-Ayyim pada hadist di atas adalah lafadz mutlaq mencakup semua wanita baik yang masih perawan ataupun sudah janda. Imam Zufar dan ulama Kufah berpendapat bahwa semua wanita baik yang sudah pernah menikah atau belum jika sudah baligh maka ia lebih berhak daripada walinya. Apabila ia menikahkan dirinya sendiri maka akad nikahnya adalah sah karena wali bukanlah syarat sah pernikahan akan tetapi hanya untuk kesempurnaan dan keutamaan pernikahan (Badr al-Din, 2000: 77). 


\section{Kebolehan istri mengambil haknya dari suami secara diam- diam}

Problem sosial pada dewasa ini adalah kesulitan dan ketimpangan ekonomi di mana pihak yang paling merasakan dampaknya adalah kaum perempuan. Banyak sekali kasus perceraian terjadi karena faktor ini di mana kaum istri ditelantarkan secara ekonomi oleh suaminya tanpa ada konsekwensi hukum baik secara perdata ataupun pidana bagi kaum lakilaki tersebut. Bahkan banyak perempuan yang dipaksa secara psikis oleh suami untuk menghidupi keluarga dengan bekerja di pabrik-pabrik sebagai buruh sedangkan suaminya menjadi pihak yang hanya ikut berperan sebagai pengantar dan penjemput saja.

Kondisi ini bertentangan dengan konsep Islam di mana seorang suami secara mutlak berkewajiban untuk menafkahi keluarganya. Dengan demikian merupakan keharaman bagi seorang suami menelantarkan istri dan anak-anaknya. Allah swt berfirman Q.S. al-Baqarah: 233:

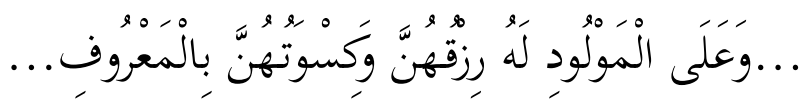

Artinya “...dan kewajiban ayah memberi makan dan pakaian kepada para ibu dengan cara yang ma'ruf...

Kewajiban memberi nafkah kepada anak dan istri merupakan kewajiban perdata yang melekat pada diri seorang suami. Dengan demikian istri berhak untuk mengambil haknya tersebut dengan atau tanpa persetujuan si suami.

'Aisyah ra meriwayatkan sebuah hadist:

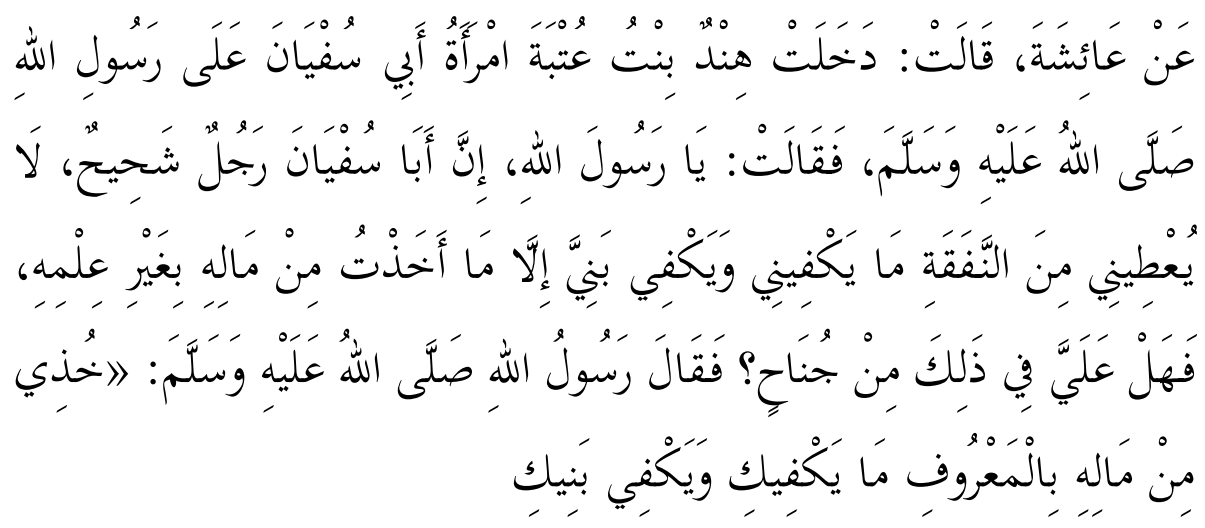


"Suatu waktu Hindun Binti 'Utbah menemui Rasulullah saw dan berkata"wahai Rasulullah sesungguhnya Abu Sufyan adalah suami yang sangat pelit ia tidak memberi nafkah yang cukup untuk diriku dan anak-anakku kecuali aku mengambil sebagian hartanya dengan tanpa izin darinya. Apakah aku bersalah dengan hal tersebut? Rasulullah saw menjawab: ambilah sebagian hartanya yang dapat mencukupi dirimu dan anakmu dengan cara yang ma'ruf (Bukhari, 1994: 200).

Hadist ini terdapat dalam kitab Bukhari dan Muslim di mana sumber pertama hadist ini dari golongan sahabat adalah 'Aisyah ra.

Hadist riwayat 'Aisyah ra ini menjadi dasar para fuqaha untuk menetapkan kebolehan seorang istri untuk mengambil secara mutlak haknya dalam rumah tangga atas suami. Hak ini terus melekat sehingga ia dapat mengajukannya kepada Qadi (hakim) sebagai hal yang menjadi hutang perdata si suami atas dirinya yang lalai tidak memberinya nafkah. Nafkah ini tidak hanya terbatas kepada makanan pokok saja akan tetapi juga termasuk buah-buahan, pakaian, keperluan hari raya dan bahkan biaya berobat (Sabiq, 1983: 151).

\section{Penutup}

Sayyidah 'Aisyah ra memiliki peran yang begitu luar biasa di dalam pembentukan hukum Islam yang berkeadilan dan memihak kaum perempuan. Peran tersebut tidak lepas dari posisinya sebagai istri Rasulullah saw juga disebabkan kecerdasan dan kepandainyya di dalam menangkap ajaran-ajaran Islam yang menekankan sifat egaliter dan kesamaan hak dan kewajiban antara laki-laki dan perempuan. Wacana yang berkembang dewasa ini terkait dengan kebebasan perempuan dalam pendidikan dan berkeluarga secara tegas sudah disinggung oleh hadist-hadist riwayat Sayyidah 'Aisyah ra. Demikian juga pentingnya perlindungan domestik bagi seorang istri di dalam mendapat jaminan kesejahteraan yang adil dalam kehidupan rumah tangga sudah disinggung dalam riwayat hadist di mana Sayyidah 'Aisyah ra meriwayatkannya dari Rasulullah saw. Hanya saja diakui atau tidak, kungkungan sosial yang lebih memihak kepentingan laki-laki (patriakhi) menjadikan hadist-hadist tersebut kurang diapresiasi secara mutlak oleh Fuqaha yang kebanyakan laki-laki. 
Estafet peran dan langkah-langkah tersebut sudah seharusnya terus diperjuangkan oleh kaum perempuan muslim sehingga akan muncul ahli-ahli fiqh dan cendikiawan muslim dari kaum perempuan yang menyuarakan keadilan tidak hanya untuk kemajuan dan perlindungan bagi kaum perempuan itu sendiri akan tetapi juga bagi seluruh umat manusia tanpa melihat perbedaan gender.

\section{DAFTAR PUSTAKA}

'Abd al-Wahhab Khallaf, 'Ilm Ushul Fiqh. Kairo: Dar al-Qalam, 1978

Abdurrahman al-Baghdady, Emansipasi adakah dalam Islam. Jakarta: Gema Insani Press, 2001

Abu Daud. Sunan Abi Daud. Beirut: Dar al-Fikr, 2003

Abu Hajjaj Yusuf al-Mazzy, Tahdzib al-Kamal fi Asma' al-Rijal. Beirut: Dar al-Fikr, 1994

Ahmad Musthafa al-Maraghi, Tafsir al-Maraghi. Beirut: Dar al-Fikr, 2001

Ali Munhanif. Editor. Perempuan dalam Literatur Islam Klasik. Jakarta: PT Gramedia Utama, 2002

Ashfgar Ali Engineer, Pembebasan Perempuan. Jogyakarta: LkiS, 2003

Bukhari, Shahih Bukhari. Beirut: Dar al-Fikr, 1995

Ibn Katsir, Tafsir Ibn Katsir. Beirut: Dar al-Fikr, 1997

Ibn Majah, Sunan Ibn Majah. Beirut: Dar al-Fikr, 2004

M.M. Azami, Hadis Nabawi dan Sejarah Kodifikasinya. Jakarta: Pustaka Firdaus, 2000

Mahmud ibn Ahmad ibn Musa Ibn Ahmad Ibn al-Husain Badr al-Din al'Ainy, al-Bayanat Syarhal-Hidayah, Juz V. Beirut: Dar al-Kutub al-'Ilmiyah, 2000

Mahmud Thahhan, Taisir Mushtalah al-Hadist. Kairo: tp: tt

Mahmud Yusuf al-Kandahlawi, Hayat al-Shahabat, juz 11. Beirut: Dar alFikr, 2006 
Muhammad Hasan Hito, Khullashah fi Ushul al-Figh. Kuwaitt: Dar alDhiya', 2005

Muhammad Sahrur, Metodologi Fiqih Islam Kontemporer, terj. Sahiron Syamsuddin. Jogyakarta: eLSAQ Press, 2004.

Muhammad Syafi'i Antonio, Ensiklopedi Leadership \&Manajemen Muhammad Saw, jilid 3. Jakarta: Tazkiya Publishing, 2010

Musthafa al-Siba'i, Al-Hadist sebagai Sumber Hukum. Bandung: Diponegoro, 1979

Nasa'i, Sunan al-Nasa'i. Beirut: Dar al-Fikr, 2005

Nurjannah Ismail, Perempuan dalam Pasungan Bias Laki-laki dalam Penafsiran. Jogyakarta: LKiS, 2003

Sa'ad Ibrahim Shalih, Qadhaya al-Mar'ah al-Mu'asharah Ru'yah Syar'iyyah wa Nadzrah Waqi'iyyah. Kairo: Maktabah Madbuly, 2008

Sayyid Sabiq, Fiqh al-Sunnah. Beirut: Dar al-Fikr, 1983 